\title{
ARTICLE
}

\section{DETECTION AND ELIMINATION VIRUS ON POTATO (Solanum tuberosum L.)}

\author{
Debora Margareth $^{1 *}$, Ida Ayu Astarini ${ }^{1}$, and I Gede Rai Maya Temaja ${ }^{2}$ \\ ${ }^{1}$ Program of Master of Biological Sciences, Faculty of Mathematics and Natural Sciences, \\ Udayana University \\ ${ }^{2}$ Program of Master of Biotechnology, Postgraduate Program of Udayana University \\ *Corresponding author: deboramargareth48@gmail.com
}

\begin{abstract}
This study aims to determine the symptoms of virus attacks on potato crops, identification of viruses that attack potato plants in Pancasari village, Bali, efectivity of thermotherapy technique to eliminate in vivo potato. The research was taken using purposive sampling technique and complete random program. Virus symptoms were observed on two potato fields. Serological test employed DAS-ELISA with PVX, PVS, PVY and PLRV antiserum. In vivo elimination virus were done by thermoteraphy in $37^{\circ} \mathrm{C} \pm 1^{\circ} \mathrm{C}$ ( 4 days), $34^{\circ} \mathrm{C} \pm 1^{\circ} \mathrm{C}$ ( 3 days) on 3 weeks and $33^{\circ} \mathrm{C} \pm 1{ }^{\circ} \mathrm{C}$ ( 4 days), $30^{\circ} \mathrm{C} \pm 1^{\circ} \mathrm{C}$ ( 3 days) on 2 weeks. Results of the study at Pancasari Village Bali shown varied symptoms on potato leaves, such as mottle, mosaic, malformation, leafroll, witchesbroom. Through serological test, had identified viruses were 11.11\% PVX, 55.56\% PVS, 80\% PVY and 11.11\% PLRV which were infected farmer's potato. In vivo thermotherapy was succeed decreasing PVS and PVY level during 2 weeks on $33^{\circ} \mathrm{C} \pm 1^{\circ} \mathrm{C}$ (4 days) and $30^{\circ} \mathrm{C} \pm 1^{\circ} \mathrm{C}$ ( 3 days).
\end{abstract}

Keywords: Thermotherapy, PVX, PVS, PVY, PLRV, DAS-ELISA

\section{INTRODUCTION}

Potato (Solanum tuberosum L.) is one of the staple food alternatives that contain carbohydrates, essential vitamins, minerals, proteins, and iron that puts this vegetable as the fourth highest food crop in the world (Fernie and Willmitzer, 2001). Today the government makes potatoes a priority for horticultural crops to be developed. Potatoes as one of the vegetables are quite popular among Indonesian people, including the people of Bali. In addition, potatoes can be consumed as snacks, diabetes therapy, other treatments, as well as beauty treatments (Pitojo, 2004).

Every year the level of community consumption of potatoes is increasingly that is not comparable with the result of its production. Recorded in the year 2016 potato productivity in Indonesia only reached 18,25 ton/ha with total production 1.213.041 ton from arera of planting 66,450 hectares. This Fig. is low compared to potato production potential in producer wich reach 40 ton/ha. 
Currently, potato cultivation in Bali is very limited. The average of potato farmers are only produce $17-20$ tons / ha of potato in one harvest. The main obstacle that complained by the farmers is the high cost of production and investment of diseases that attack the crop (Wardana, personal communication, 2016).

Good potato cultivation requires quality and certified seeds where the seed price is high enough. Generally, the farmers use local seeds from generation to generation to more than 4th generation, so they have a high chance of investing in viruses that contain 6-7 times of the virus and can decrease the potato production result (Mulyana, 2005; Pradjadinata, 2005).

The main systemic diseases that are commonly found in potatoes are Potato Leaf Roll Virus (PLRV) of about 25-90\%, Potato Virus Y (PVY), Potato Virus X and Potato Virus about 5-80\% (Brunt, 2001; Duriat et al., 2006). Losses that can be caused by PVY range from 30 - 50\% (Feng et al., 2013). In potato-producing countries such as China, India, and the United States, potato production drops from viral infection by $80 \%$ (Brunt, 2001). Potato Virus X (PVX) infections that attack potato crops reduces production by $30 \%$ in India (Reddy, 2010).

The aim of this research is to know the symptom of virus attack on potato crops, the type of the virus that attacking potatoes of Granola varieties in Pancasari Village, Bali and to know the effectiveness of therapeutic technique in eliminating virus in potato in vivo. This information is expected to provide information on virus attacks and solutions to get the good quality of potato seeds that are free of virus so as to increase the production of potatoes.

\section{MATERIALS AND METHODS}

The observations were conducted in 2 farmers' lands to identify the symptoms of a viral attack. The sample of symptomatic potato leaf was taken by done a purposive sampling technique on 27 symptomatic plants. Potato harvests from symptomatic plants are observed tubers (shape, size, tuber skin bulbs). Serology test with DAS-ELISA was according to the recommended of the protocol Agdia, USA. Testing the virus using ELISA Kit PVX, PVS, PVY and PLRV. The test sample was tested positive for virus infection; if the ELISA Reader refer of value that shown $\geq 2$ times of the absorbance value that had been read on the negative control. Completely randomized Design is used when the treatment is term heat. The therotherapy was performed at $37^{\circ} \mathrm{C}$ (4 days) and $34^{\circ} \mathrm{C}(3$ days) for 3 weeks, also at $33^{\circ} \mathrm{C}$ (4 days) and $30^{\circ} \mathrm{C}$ (3 days) for 2 weeks.

\section{RESULTS AND DISCUSSION}

\section{Symptoms On Leaf}

The easiest way to observe the virus attack on potato crops in the land is to 
observe of the leaves and the plant habitus. mosaic, malformation, curl, dwarf, rugose, There are three types of abnormalities in witchesbroom, and wavy edges (Fig. 1). potato that attack by the virus i.e mottle,
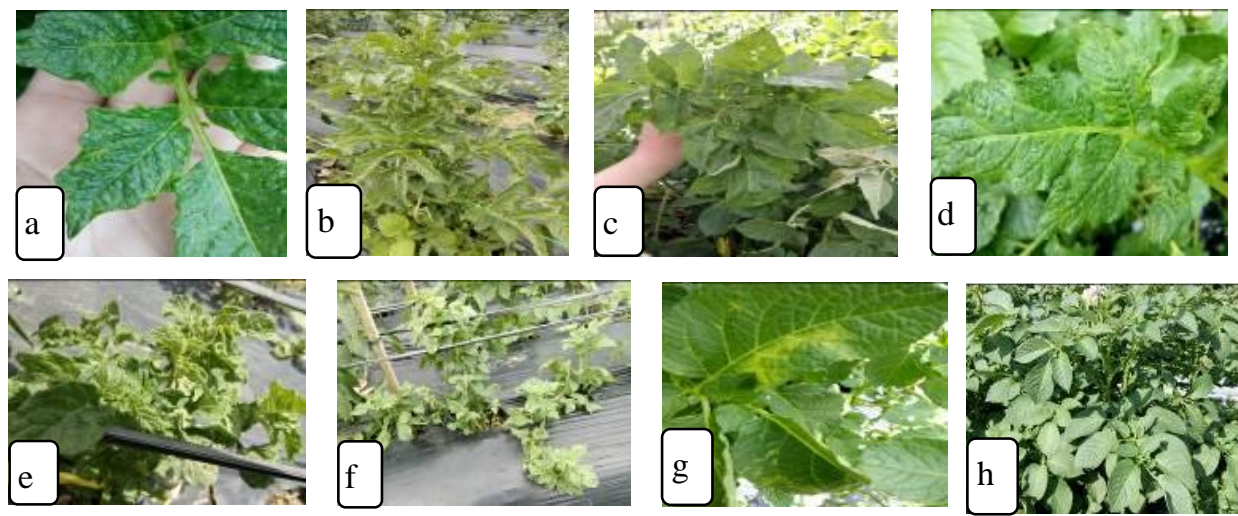

Fig. 1. Symptoms of leaf that infected by the potato virus on land $A$ and $B$. a. malformation, b. rolling, c. mosaic, d. rugose, e. dwarf, f. witchesbroom, g. mottle, h. normal leaves.

The local farmers do not realize that the plants with these characteristics may be containing of viruses. In general, the plant looks healthy with green leaves different from the plants that attack by the other diseases such as Fusarium sp and Phytophthora sp, it's clearly visible if it attacks the potato plants because it can cause a wilting, a dry, until a death in plants. The plants that attacked by the virus do not directly kill the plants, but the impact on the decrease of crops.

\section{Crop Harvest}

The presence of virus in potato plants is very influential on the harvest. The decrease of harvested tubers is about $40 \%$ $80 \%$ seen in fewer tuber counts and fewer tubers of smaller size when compared to tubers from healthy plants. Farmers harvest potato tubers at the age of 95-100 days after planting. The following table shows potato tuber yields from symptomatic plants and healthy plants (Table 1).

Table 1 Potato Bulbs Weight from Plants Symptomatic and Healthy Plants

\begin{tabular}{llccc}
\hline No & \multicolumn{1}{c}{ Sample } & \multicolumn{2}{c}{$\begin{array}{c}\text { Average of total weight of tuber } \\
\text { per plant }(\mathbf{g}) \pm \text { S.e }\end{array}$} & \multirow{2}{*}{$\begin{array}{c}\text { Average } \\
\end{array}$} \\
\cline { 3 - 4 } & & $1316^{\mathrm{a}} \pm 60,0$ & $1266^{\mathrm{a}} \pm 92,6$ & \\
\hline 1 & Healthy Tuber & $330^{\mathrm{c}} \pm 90,0$ & $703^{\mathrm{b}} \pm 173,2$ & $1291^{\mathrm{a}}$ \\
2 & Plant bulbs leaf rol & $333^{\mathrm{c}} \pm 82,5$ & $250^{\mathrm{c}} \pm 40,4$ & $516^{\mathrm{bc}}$ \\
3 & Plant mosaic tuber & - & $493^{\mathrm{bc}} \pm 201,7$ & $291^{\mathrm{c}}$ \\
4 & Tuber plant witchesbroom & $783^{\mathrm{b}} \pm 93,8$ & $730^{\mathrm{b}} \pm 160,9$ & $246^{\mathrm{c}}$ \\
5 & Plant bulbs malformations & $760^{\mathrm{b}} \pm 147,4$ & $456^{\mathrm{bc}} \pm 173,8$ & $756^{\mathrm{b}}$ \\
6 & Plant mottle tubers & & $540^{\mathrm{bc}}$ \\
\hline
\end{tabular}

Description: The average value of 3 plants for each symptom. The numbers followed by the same letter in the same column are not significantly different. 

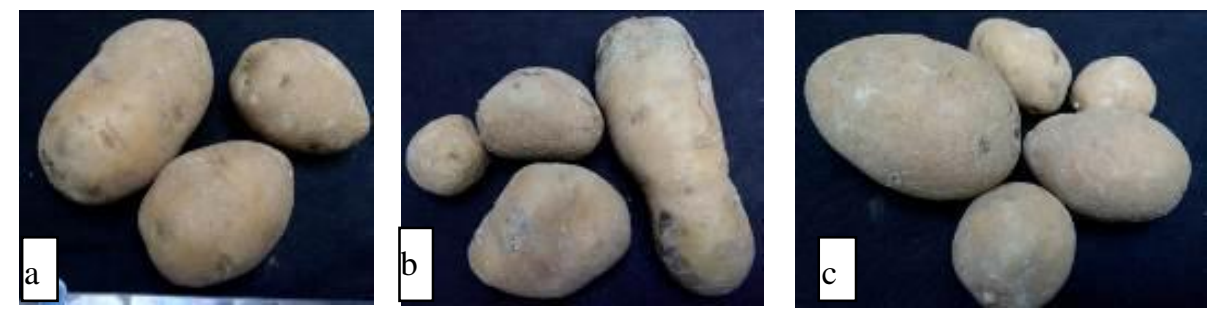

Fig. 2. Potato tuber of Granola varieties on land A.

a. Healthy tubers (control); b. Tubers of infected symptomatic plants that infected by the PVX and PVS (long tubers, tuber malformations, tubers growing) c. Tubers from mosaic symptomatic plants that infected by the PVS (scaled tuber skin, tuber malformation).

The presence of virus in potato crops is very influential on the harvest (Fig. 2, Fig. 3). The effect is seen in relatively the fewer tuber quantities and the smaller size when it compared to the potato tubers from a healthy plants.

\section{Detection of Potato Virus with DAS- ELISA Technique}

The plant samples were obtained from 2 different lands. Based on the symptoms was found in the two lands, the confirmation of the presence of virus in potato plants using the DAS-ELISA serology test had been done (Table 2, Table 3).

The result of serology test by DASELISA was showed that some positive plants were infected with PVX, PVS, PVY, and PLRV. Based on the percentage of disease incidence in 27 samples of Granola potato crops varieties in Pancasari Village, Bali was predominantly infected with Potato Virus Y and Potato Virus S (Table 4).
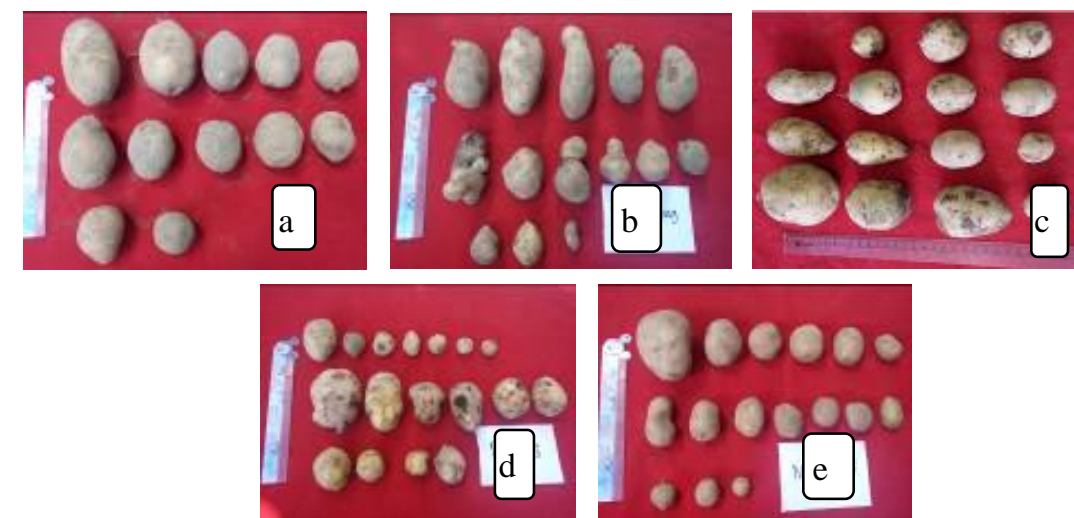

Fig. 3. Potato Granola potato tube on Land B

Description: a. Healthy tubers (control); b. Tubers from symptomatic plants to roll up infected PVY (long tuber, tuber stick together, tuber such as ginger rhizome); c. Potato tubers from mammal-infected plants infected with PVS, PVY and PLRV (more conical bulbs); d. Tubers from witchesbroom symptomatic plants infected with PVS and PVY (tuber malformations, small tuber size); e. Tubers from symptomatic plants infected leaf malformation of PVS and PVY (tuber malformation, small tuber size). 
Table 2. The Average Absorbance Score of the Sample on Land A

\begin{tabular}{ccccc}
\hline Sample & \multicolumn{3}{c}{ Average Absorbance Score } & \multirow{2}{*}{ Description } \\
\cline { 2 - 4 } Roll (Mg) & PVX & PVS & PLRV & \\
\cline { 2 - 4 } & $\mathbf{0 , 8 8 6}$ & $\mathbf{3 , 5 1 3}$ & 0,128 & \\
Mottle (Mo) & 0,171 & 0,137 & 0,127 & Positive of PVX \\
and PVS & Negative \\
Mosaic (Ms) & 0,176 & $\mathbf{1 , 4 3 8}$ & 0,129 & Positive of PVS \\
Malformation (Ma) & 0,178 & 0,138 & 0,134 & Negative \\
Control (-) & 0,125 & 0,117 & 0,122 & \\
2x kontrol (-) & 0,25 & 0,234 & 0,245 & \\
\hline
\end{tabular}

Table 3. The Average Absorbance Score of the Sample on Land B

\begin{tabular}{cccccc}
\hline Sample & \multicolumn{4}{c}{ Average Absorbance Score } & \multirow{2}{*}{ Description } \\
\cline { 2 - 5 } & PVX & PVS & PVY & PLRV & \\
\hline Mosaic (Ms) & 0,165 & $\mathbf{1 , 8 1 3}$ & $\mathbf{3 , 5 3 4}$ & $\mathbf{1 , 4 1 2}$ & Positive of PVS, \\
& & & & & PVY, PLRV \\
Mottle (Mo) & 0,169 & 0,129 & 0,102 & 0,113 & - \\
Roll (Mg) & 0,149 & 0,120 & $\mathbf{3 , 7 4 8}$ & 0,11 & Positifve of PVY \\
Malformation & 0,124 & $\mathbf{2 , 6 2 2}$ & $\mathbf{3 , 7 1 5}$ & 0,105 & Positive of PVS and \\
(Ma) & & & & & PVY \\
Witchesbroom & 0,133 & $\mathbf{2 , 7 7 9}$ & $\mathbf{3 , 7 2 7}$ & 0,135 & Positive of PVS and \\
& & & & & PVY \\
Control (-) & 0,102 & 0,106 & 0,120 & 0,143 & \\
2x Control (-) & 0,204 & 0,212 & 0,239 & 0,287 & \\
\hline
\end{tabular}

Table 4. Virus Disease Incidence Based on Serological Test Results

\begin{tabular}{ccccc}
\hline Location & \multicolumn{4}{c}{ Disease Occurrence (\%) } \\
\cline { 2 - 5 } & PVX & PVS & PVY & PLRV \\
\hline Land A & 25 & 50 & - & 0 \\
Land B & 0 & 60 & 80 & 20 \\
Total & 11,11 & 55,56 & 80 & 11,11 \\
\hline
\end{tabular}

${ }^{1}$ Disease Occurrence $=\mathrm{n} / \mathrm{N} \times 100 \%$, where $\mathrm{n}=$ number of positive plants infected virus, $\mathrm{N}=$ number of plants tested.

\section{Potato Thermotherapy}

The virus elimination in potato can be done by applying the thermotherapy method. Potato tuber tubes that detected by PVX, PVS, PVY and PLRV are samples for viral elimination with the technique.

Thermotherapy was performed on a sample of harvested potato tubers on land A (Fig. 4) and harvested potato tubers on the soil B (Fig. 5). 

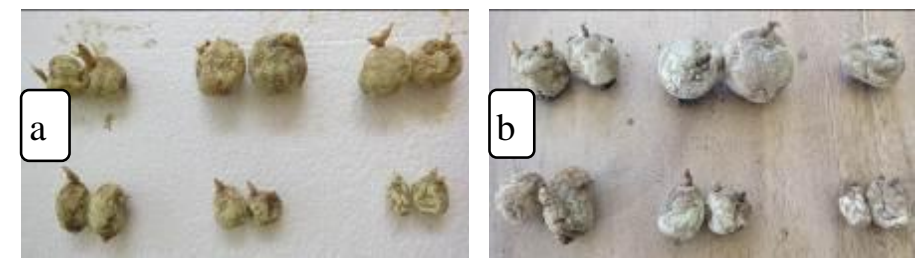

Fig. 4. Thermotherapy results of the potato tuber of the first land.

a. before thermotherapy (tubers and healthy shoots), b. after thermotherapy (some rotten tubers, some shoots withered and dried)
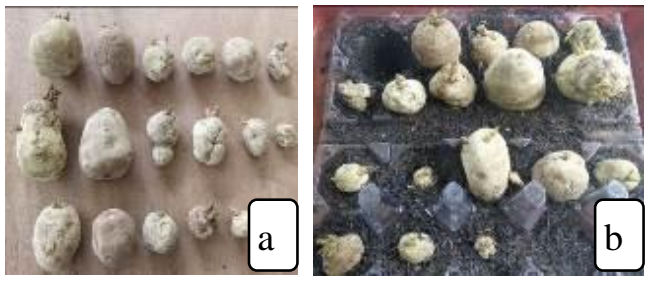

Fig. 5. Thermotherapy results of potato tuber of the second land.

a. before thermotherapy (good tuber), b. after thermotherapy (one rotten tuber, grew roots and shoots on several tubers)

\section{Confirmation of Elisa after Themotherapy}

The serological tests on potato leaf samples were performed before and after heat treatment was applied. The following table presents a comparison of serological test results using serum PVS and PVY (Table 4).

Table 5. Comparison of Test Results of DAS-ELISA Potato Thermotherapy.

\begin{tabular}{ccccc}
\hline Gejala & \multicolumn{2}{c}{ PVS } & \multicolumn{2}{c}{ PVY } \\
\cline { 2 - 5 } & TT & DT & TT & DT \\
\hline Roll Up & - & - & 3,748 & 0,343 \\
$\begin{array}{l}\text { Witchesb } \\
\text { room }\end{array}$ & 2,779 & 1,266 & 3,727 & 0,311 \\
& & & &
\end{tabular}

TT: without thermotherapy, DT: with thermotherapy.

\section{DISCUSSION}

\section{Identification of Virus Symptoms in Potatoes}

Potato leaf plants with leaf-rolled symptoms have been shown to be infected with PVX, PVS, and PVY based on the
DAS-ELISA serology test performed, in contrast to Burrows and Zitter reports (2005), in the American leaf rolling, upright, chlorotic and dwarfed symptoms are indicative of PLRV infection. In contrast to the characteristics of PVX infection indicated by symptoms of chlorosis, mosaic, rugose, dwarf, and reduced leaf size (Burrows and Zitter, 2005; Kumar, 2013).

Infection from Potato Virus $Y$ and Potato Virus $S$ is the dominant found in this research. Both of these viruses express the varied symptoms of rolled leaves, mosaics, malformations and witchesbroom. PVY generally presents a variety of mosaic symptoms, necrosis, leaf wrinkles, until premature death in plants (Burrows and Zitter, 2005; Kumar, 2013). Most potato cultivars of its attack symptoms are difficult to detect visually. Variation of symptoms in 
potato leaf found is a result of viral infection. Virus strains, crop varieties, environmental conditions and the presence of viral mixed infections in plants are some of the factors that cause the variety of symptoms seen in each plant. Mixed viral infections in plants commonly occur in nature causing interaction of various symptoms (Syller, 2012; Burrows and Zitter, 2005; Kumar, 2013).

Virus infections in potato plants also result in high levels of loss of potato crop yields. Loss of yields due to infection of PVX and PVS mixtures on land A of $74 \%$. The highest yield decrease in B land is due to mixed infection between PVS, PVY and PLRV up to $80 \%$. Mixed infections between PVS and PVY reduced yield by $61 \%$, whereas single PVY infections reduced yield by $44 \%$. The decline of these results is in accordance with the statement of Hameed et al. (2014) that is associated with a viral infection infection in plants where disease progression will be more severe and higher viral accumulation in mixed infections compared with single infections of these viruses.

Mottle and dwarf symptoms in this reasearch were not confirmed ELISA, this is probably because the potato plants are infected with viruses other than PVX, PVS, PVY and PLRV or lack of certain nutrients. Mottle on the potato leaf is likely due to lack of magnesium $(\mathrm{Mg})$ or iron $(\mathrm{Fe})$ elements such as in tomato plants (Sawyer, 2004).

Transmission of the virus can occur through aphids as well as agricultural tools. In addition to transmitting the virus, aphids also suck fluid contained in the leaves, consequently the shape of the leaves can be changed (Blackman and Eastop, 2000). The existence of the virus is not only from seed sources that contaminated with the virus before, but also from the spread of aphids on potatoes in the field. Plants are afflicted aphids are usually found also ants who like honey dew as the feed is secreted by aphids. While the exudate is not utilized by ants will encourage the growth of sooty fungi on the leaves that can inhibit the process of photosynthesis (Pracaya, 2007).

Abnormal leaf shape such as rolling, leaf malformation, wavy leaf, rugose, leaves that accumulate (witchesbroom) resulted in reduced leaf surface area, so the ability of photosynthesis is also reduced. This is resulted of photosynthesis was declining and visible in the resulting tuber became not maximal.

The process of photosynthesis is impaired due to changes and abnormal chloroplast functions that caused by viruses. Toxins are released by pathogens also inhibit the process of phosphorylation and protein of synthesis (Yunasfi, 2008). The leaves are attacked by the virus will experience the efficiency of chloroplast so that the leaves 
occur changes in shape, size, clotting chloroplasts, and the accumulation of starch. Overall, this viral infection will decrease the chlorophyll content of the plant (Goodman et al., 1986).

Incomplete photosynthesis affects potato tuber replenishment. Tuber potato tubers that are detected by the virus will tend to be small, the number of tubers a little, and the shape of the tuber is not appropriate, but it is also influenced by the intercropping physiological competence (Allen, 1972). Symptoms that had seen in the tubers are due to the transport of photosynthates from the source to the sink are disturbed by the presence of viruses that control phloem in plant tissue (Ariyanti, 2011). Secondary infections, excessive water stress after a period of drought, and overheated temperatures can also affect the filling of potato tubers that resulting in imperfect tuber form (CIP-Balitsa, 1999).

\section{Virus on Planting as well as DAS ELISA}

\section{Serology Test Result}

Mixed viral infections that were detected after the DAS-ELISA serology test was performed were likely due to the spread of aphids in the land. This is evidenced by the presence of aphids that found in some potato leaf samples in the land, so potentially causing mixed infections naturally in nature (Syller, 2012; Damayanti et al., 2015). The dominant mixed infection was occurring in
Pancasari is between PVS and PVY in compared with other mixed viral infections. PVY infection is only detected in farmer cultivation on land $\mathrm{A}$, this is because the availability of ELISA Kit for PVY is fulfilled when the B serology test is performed. Based on the research of Hameed et al. (2014), in Pakistan the highest mixed infection was occured between mixed infection of PVX and PVS. Mixed infections were also found in the United States and Greece that were caused by a mixed infection between PVY, PLRV, and PVX (Baldauf et al., 2006; Chatzivassiliou et al., 2008).

Loss of the results by $50 \%$ was occurred due to a mixed infection between PVX and PVY (Brunt, 2001). The decrease in farmers' harvests can be attributed to the presence of viral infection in plants, where disease progression will be more severe and higher viral accumulation in mixed infections was compared with single infections of these viruses (Hameed et al., 2014).

The mosaic symptoms of the leaves gave the highest influence on these potato tuber yields. This was similar to the statement of Taiz and Zeiger (2002), that leaves with the greener colors contain high chlorophyll, so photosynthesis could run well and is used in the formation of carbohydrates for tubers. The decreased chloroplasts that content due to viral attack affects the potato tubers produced (Goodman et al., 1986). The reduced surface area of the leaves due to the 
virus attack was occurred in the symptomatic leaves of rolls, malformations and witchesbroom. Decreased leaf surface area results in decreased photosynthesis (Yamacuchi, 2008). The same is expressed by Balachandran et al. (1994) who reported that the development of tobacco leaves was disrupted by viral infections.

\section{Effort of Potato Virus Elimination by}

\section{Using Theremotherapy Technique}

Thermotherapy is treated on potato crops harvested from the farmers. Potatoes on land A as a result of thermotherapy with $37^{\circ} \mathrm{C}$ (4 days) and $34^{\circ} \mathrm{C}$ (3 days) for 3 weeks were unlikely to survive. Potato tubers do not survive suspected because of the hot and humid conditions that allow contamination of the fungus and bacteria, as well as relatively thin layers of potato skin and the water content of potato tubers favored by microbes (Pujimulyani, 2009; Nasution, 2017).

Potatoes on land B that column of the symbiotic mosaic, curved and witchesbroom were treated at $33^{\circ} \mathrm{C}$ (4 days) and $30^{\circ} \mathrm{C}(3$ days) for 2 weeks with percentage of potato surviving potatoes i.e up to $95 \%$. The use of alternate range of temperatures aims to avoid damage to plant tissue so that the expected percentage of plant life is high, while the duration of heat treatment can affect the efficiency of virus elimination (Faccioli and Rubies-Autonell, 1982; Tan et al., 2010).
Thermotherapy are able to suppress the presence of PVS and PVY in potato plants, through serological test results shown from the rolled sample and witchesbroom. Virus concentrations in the sample decreased when viewed from the absorbance value of reading Elisa reader of PVS of $55.8 \%$ and PVY of $90.8 \%$ supported by the statement Balamuralikrishnan et al. (2003), that hot temperatures have an impact on the decline of Sugarcane Mosaic Virus (SCMV) titer due to viral inactivation.

Szittya et al. (2003); Wang and Valkonen. (2008) also stated that low viral concentrations in plants are often associated with high temperature exposure, where with temperatures exceeding the optimum temperature of plant growth the pathogen multiplication can be suppressed and viral RNA degradation increases. Thermotherapy is also able to inhibit viral RNA synthesis so that it has the potential to decrease the synthesis of protein movement in which viral transport is impaired and damage coat proteins that play a role in virusic systemic translocation in plants (Bhojwani and Dantu, 2013; Hadidi et al., 1998).

The success of thermotherapy techniques in this study although not yet able to completely eliminate the virus but has been able to reduce the viral concentration in the sample plants, this is in accordance with research Duriat et al. (1986) that potato tuber storage at hot temperatures can lower the 
content of the virus in potatoes by up to $67 \%$, and potato tubes with hot water treatment effectively reduce PVY levels by up to $40 \%$ (Petrov and Lyubenova, 2011).

Based on the results of this in vivo thermotherapy, farmers could take advantage of thermotherapy techniques with a temperature that not too high and in a relatively shorter time. Utilization of solar heat is not recommended for this thermotherapy process, this is because the heat from the sun every day is not constant (Duriat et al., 1986). So we need a room with the appropriate temperature settings for done the thermotherapy.

\section{ACKNOWLEDGEMENT}

The authors are grateful to $\mathrm{Mr}$. Ngenteg and Mr. Komang Nyadne for the land use permittion for doing the research, to Khairun Nisak Syahdu, S.P., M.P who has assisted the DAS-ELISA test at the Agriculture Quarantine Center of Class 1 Denpasar.

\section{REFERENCES}

Allen, E. J. (1972). Relationship Between Stem Number and tuber in the Potato Crop. J. Agric. Sci., Cambridge, 79, 315-320.

Ariyanti, N. A. (2011). Mekanisme Infeksi Virus Kuning cabai (pepper yellow leaf curl virus) dan Pengaruhnya Terhadap Proses Fisiologi Tanaman Cabai. Universitas Negeri Yogyakarta.
Seminar nasional viii pendidikan biologi.

Balacandran, S., Osmond, C. B., \& Makino, A. (1994). Effect of Two Strain of Tobacco Mosaic Virus on Photosynthetic Characteristics and Nitrogen Partitioning in Leaves of Niccotiana tabaccum CV Xanthi During Photoacclimation Under Two Nitrogen Nutrition Regimes. Journal Plant Physio, 104, 1043-1050.

Baldauf, P. M, Gray, S. M., \& Perry, K. L. (2006). Biological and erological properties of potato virus $\mathrm{Y}$ isolates in north eastern United States potato. Plant Dis, 90, 559-66.

Blackman, R. L., \& Easatop, V. F. (2000). Aphid's on the World's Crop: An Identification and Information Guide $2^{\text {nd }}$ ed. Wiley, Chichester. 181-185.

Brunt, A. A. (2001). The main viruses infecting potato crops Loebenstein $\mathrm{G}$, Berger, PH, Brunt, AA \& Lawson RH, (eds.), Virus and virus-like diseases of potatoes and production of seedpotatoes, Kluwer Academic Publishers, Dordrecht (NL), pp 65-7.

Burrows, M. A., \& Zitter, T. A. (2005). Virus Problems of Potatoes. Vegetable MD Online. USDA-ARS and Department of Plant Pathology, Cornell University, Ithaca.

Chatzivassiliou, E. K., Moschos, E., Gazi, S., Koutretsis, P., \& Tsoukaki, M. (2008). Infection of potato crops and seeds with potato virus $\mathrm{y}$ and potato leafroll virus in greece. J. phytopathol, 90(2), 253-261.

CIP, \& Balitsa. (1999). Penyakit, Hama dan Nematoda Utama Tanaman Kentang. 124 hal.

Damayanti, T. A., \& Kartika, R. (2015). Deteksi Virus-virus pada Kentang di Jawa Barat dengan Menggunakan Teknik Molekuler. J. Hort, 25(2), 171179.

Duriat, A. S., Wibiksana, E., \& Sofiari, E. (1986). Pengaruh pemanasan terhadap gejala virus daun menggulung (PLRV) pada umbi bibit kentang. Buletin 
Penelitian Hortikultura XIV, (2), 1528.

Duriat, A. S., Gunawan, O. S., \& Gunaini, N. (2006). Penerapan Teknologi PHT pada Tanaman Kentang. Monograf. Balai Penelitian Tanaman Sayuran. 59 hlm.

Feng, C. R., Wang, J., Li, B., Wang, Z., Yin, Z., Cui, B., Li, W., Bi, Z., Zhang, M., \& Li, Q. W. (2013). Production of Pathogen-Free Horticultural Crops by Cryotherapy of In Vitro-Grown Shoot Tips. Lambardi M. (Ed.), Protocols for Micropropagation of Selected Economically-Important Horticultural Plants, Methods in Molecular Biology. Springer Science+Business Media New York.

Fernie, A. R. \& Willmitzer, L. (2001). Molecular and Biochemical Triggers of Potato Tuber Development. Plant Physiology, 127, 1459-1465.

Goodman, R. N., Kiraly, Z., \& Wood, K. R. (1986). The Biochemistry and Physiology of Plant Diseases. Columbia: Univ of Missouri Pr. Hlm 507-523.

Hameed, A., Iqbal, Z., Asad, S., \& Mansoor, S. (2014). Detection of Multiple Potato Viruses in the Field Suggests Synergistic Interac-tions among Potato Viruses in Pakistan. Plant Pathol. J, 30(4) : 407-415 Mulyana, A.J. 2005. Penyebaran potato virus Y (PVY) di
Sentra Produksi Tanaman Kentang Jawa Barat. Skripsi. Fakultas Pertanian Universitas Padjadjaran, Bandung. 60 hlm.

Petrov, N., \& Lyubenova, V. (2011). Thermotherapy and Electrotherapy of Potato Tubers Infected With Potato Virus Y-PVY. Scientific Papers, 678685.

Pitojo, S. (2004). Benih Kentang. Kanisius: Yogyakarta.

Pracaya. (2007). Hama dan Penyakit Tanaman. PT Penyebar Swadaya: Jakarta.

Pradjadinata, M. (2005). Health certification on potato seed. A case for vegetative planting material. Manual of 2nd Hortin- Seed Workshop: Seed health management on vegetables. Collaboration of IVEGRI (Indonesia) and PRI (the Netherlands). Lembang. (125-131).

Sawyer, J. (2004). Nutrient Deficiencies and Application Injuries in Fiels Crops. Iowa States University.

Syller, J. (2012). Facilitative and antagonistic interactions between plant viruses in mixed infections. Mol. Plant Pathol, 13(2), 204-16.

Yamacuchi, A. (2008). Viral Lesion Formation on Chlorophyll Deficient Leaf Area. Journal of Phytopathology, 61(4), 399-400. 